\title{
PENINGKATAN PRESTASIBELAJAR MATEMATIKATENTANG PENJUMLAHAN DAN PENGURANGAN BILANGAN BULAT MELALUI PERMAINAN MISTAR BILANGAN DI SEKOLAH DASAR
}

\section{THE INCREASING OFLEARNING ACHIEVEMENT OF MATH ABOUT ADDITION AND REDUCTION OF INTEGERS USINGRULER NUMBERS GAME IN ELEMENTARY $S C H O O L$}

\author{
Titik Umiyati \\ SDN 2 Temengeng Kec. Sambong Kab. Blora \\ umiyatiparlanparlan@yahoo.co.id \\ Naskah diterima: 11/05/2016, direvisi akhir: 23/05/2016, disetujui: 15/06/2016
}

\begin{abstract}
Abstrak: Tujuan penelitian ini adalah untuk mengkaji proses pembelajaran matematika dan menganalisis peningkatan prestasi belajar melalui permainan mistar bilangan. Metode penelitian yang digunakanadalah penelitian tindakan kelas yang dilaksanakan sebanyak 2 siklus. Subjek penelitian ini adalah siswa kelas IV SD Negeri 2 Temengeng Kabupaten Blora pada semester 2 tahun pelajaran 2014/2015. Teknikanalisis yang digunakandeskriptif komparatif, yaitu membandingkan data hasil antara prasiklus, siklus I, dan siklus II. Hasil penelitian yang dilaksanakan 2 siklus menunjukkan bahwa proses pembelajaran matematika dengan menggunakan permainan mistar bilangan sangat menyenangkan siswa, sehingga aktivitas pembelajaran meningkat dari 62,5 menjadi 84,5. Hasil belajar siswa juga meningkat ditandai hasil siklus I nilai rata-rata kelas 60,48 dan ketuntasan mencapai 57,10\%. Siklus II nilai rata-rata kelas 75,24 dan ketuntasan $85,70 \%$. Simpulan penelitian ini adalah pembelajaran matematika tentang penjumlahan dan pengurangan bilangan bulat melalui permainan mistar bilangan dapat meningkatkan aktivitas pembelajaran dan hasil belajar menunjukkan semua siswa berminat dalam melaksanakan tugas dan memperoleh pengalaman yang menyenangkan dalam permainan mistar bilangan.
\end{abstract}

Kata kunci: prestasi belajar, bilangan bulat, permainan mistar bilangan

Abstract: The purpose of this research is to study the learningprocess ofmath and analyse increasing of learning achievement through rulernumbers game. The method usedin this research is class action which is done in 2 cycles. The subject of the research are fourth grade students of Number 2 PublicElementary Schoolat Temengeng, Blora district in second semester of the school year 2014/2015. The analysetechnicusedby comparingthe data from precycle, first cycle and second cycle. The results of the research that is done two cycles indicate that math learning process by using ruler numbers game can make the students feel pleased so thatlearning activities increase from 62.5 to 84.5. The results of student learning alsoincrease, it can be showed from the average score of the first cycle is 60.48 and the completeness score reaches $57.1 \%$. The average score of thesecond cycle is 75.24 and the completeness score reaches $85.7 \%$. The conclusion of the research ismath learning about addition and deduction of integer through ruler numbers game can improve learning activity and the results of student learning show that all students are interested to obtain the task and get moreenjoyable experience in using rulernumbers game.

Key word: learningachievement, integers, rulernumbers game 


\section{PENDAHULUAN}

Matematika merupakan bagian dari kehidupan sehari-hari kita. Disadari atau tidak, setiap hari kita selalu berhubungan dengan matematika (David, 2006: 2). Terasa bahwa matematika dekat dengan diri kita. Tidak hanya di sekolah melainkan juga ketikamenjumlah, mengalikan, mengurangi, membagi bilangan, membaca diagram, dan grafik. Setiap saat kita selalu bergulat dengan matematika seperti berbelanja membeli barang, bermain komputer, bermain layanglayang, membaca jadwal keberangkatan bus atau kereta api, membuat mainan, membuat kue, dan masih banyak lagi yang berhubungan dengan matematika. Ilustrasi ini menunjukkan bahwa matematika begitu sangat penting.

Pembelajaran matematika di Sekolah Dasar diarahkan pada pendekatan lingkungan terdekat siswa yang dapat membangun pribadi siswa yang mencintai matematika, sehingga dapat menerapkan dalam kehidupan seharihari. Pada dasarnya, dalam kehidupan seharihari siswa berhadapan dengan hitunghitungan yang berhubungan dengan matematika.

Perluasan himpunan bilangan asli menjadi bilangan bulat tidakhanya sekedar memenuhi kebutuhan yang berbentuk $\mathrm{a}+\ldots=$ $\mathrm{b}$, dengan $\mathrm{a}>\mathrm{b}$, melainkan jugauntuk proses penghitungan yang lebih luas lagi dalam kehidupan nyata, seperti untuk melakukan pembukuan, pemasaran, perdagangan, industri dan iptek. Selain itu,untuk melakukan proses hutang piutang, maju mundur, dan atas bawah.

Operasi bilangan bulat telah diperkenalkan di kelas IV SD yangmeliputi penjumlahan, pengurangan, perkalian dan pembagian, secara spirallebih mendalam sampai di kelas VI. Selama ini sudah cukup banyak buku-buku SD yang menyampaikan ilustrasi dan materi bilangan bulat dengan bervariasi, namun kurang tepat dan terlalu abstrak. Padahal dalam usia sekolah dasar, proses abstraksi siswa masih perlu dibantu media lain. Hampir semua buku tidak menjelaskan kenapa harus ada bilangan negatif dan bagaimana proses penentuan bilangan negatifdantidak dipergunakan media tertentu yang dapat memperlihatkan hasil operasi hitung secara realistik.

Kemampuan siswa kelas IV SDN 2 Temengeng, Kecamatan Sambong, Kabupaten Blora, semester 2, tahun pelajaran 2014/2015dalam hal penyelesaian soal penjumlahan dan pengurangan bilangan bulat relatif masih kurang. Hal ini ditunjukkan dalam proses pembelajaran awal, masih sedikit siswa yang tuntas belajarnya sebesar28,6\% atau sebanyak 6 siswa, sedangkan $71,4 \%$ atau 15 siswa belum tuntas. Pada pembelajaran awal ini nilai rata-rata kelas sebesar 45,24 kurang dari kriteria ketuntasan minimal (KKM)sebesar55.Halini berarti pencapaian siswa beradadibawah standar.

Oleh karena itu,perlu dilakukan penelitian tindakan kelas. Penelitian ini 
dilakukan untuk mengetahui sejauh mana siswa mampu menyelesaikan soal penjumlahan dan pengurangan bilangan bulat melalui permainan mistar bilangan. Permainan mistar bilangan dipilih, karena siswa umumnya sering melakukan permainan ini saat istirahat sekolah dan mengisi waktu luang di rumah. Dalam kegiatan ini guru bertindak sebagai pemandu, juri, dan fasilitator.

Dengan penerapan teknik permainan pembelajaran materi penjumlahan dan pengurangan bilangan bulat, siswa bersama kelompoknya melakukan kegiatan diskusi. Penggunaan permainan ini penting, karena pembelajaran operasi bilangan bulat di kelas IV ini masih pada tahap konkret,sehinggapenyajian materi harus dilakukan melalui tindakan anak secara langsung dan anak terlibat dalam memanipulasi atau mengotak-atik objek (Dwiyanto, 2008: 12). Pada tahap ini, anak belajar pengetahuan secara aktif, menggunakan permainan konkret padasituasi nyata, karena pada tahap ini anak belum bisa menggunakan imajinasi atau kata berkenaan dengan operasi bilangan bulat.

Model permainan mistar bilangan dalam pembelajaran penjumlahan dan pengurangan bilangan bulat dipilih karena dengan model pembelajaran ini memungkinkan dan memberi kesempatan kepada siswa untuk mencari penyelesaian soal berkaitan dengan penjumlahan dan pengurangan bilangan bulat, dengan media pembelajaran yang dibuat sendiri oleh siswa dan pembelajaran yang kontekstual. Siswa akan merasa termotivasi dan mempunyai kemampuan untuk memperoleh jawaban melalui bentuk permainan dengan mudah.

Berdasarkan latar belakang di atas maka permasalahan yang dibahas dalam penelitian ini adalah1) Bagaimana proses pembelajaran matematika tentang penjumlahan dan pengurangan bilangan bulat melalui permainan mistar bilangan pada siswa kelas IV SDN2Temengeng, Kecamatan Sambong, Kabupaten Blorasemester 2, tahun pelajaran 2014/2015? dan 2) Seberapa besar peningkatan prestasi siswa setelah mengikuti pembelajaran matematika tentang penjumlahan dan pengurangan bilangan bulat melalui permainan mistar bilangan pada siswa kelas IV SDN 2 Temengeng, Kecamatan Sambong, Kabupaten Blora semester 2,tahun pelajaran 2014/2015?

Berdasarkan permasalahan di atas maka tujuan penelitian ini adalah 1) mengkajiproses pembelajaran matematika tentang penjumlahan dan pengurangan bilangan bulat melalui permainan mistar bilangan pada siswa kelas IV SDN 2Temengeng, Kecamatan Sambong, Kabupaten Blorasemester 2, tahun pelajaran 2014/2015 dan2) menganalisisseberapa besar peningkatan prestasi belajar siswa setelah mengikuti pembelajaran matematika tentang penjumlahan dan pengurangan bilangan bulat melalui permainan mistar bilangan pada siswa kelas IV SDN 2 Temengeng, Kecamatan 
Sambong, Kabupaten Blora semester 2,tahun pelajaran 2014/2015.

Hasil pelaksanaan penelitian tindakan kelas ini akan memberikan manfaat yang langsung maupun tidak langsung kepadasiswa, guru, dan sekolah. Manfaat penelitian bagi siswa adalah 1) dapat meningkatkan kemampuan siswa dalam menyelesaikan penjumlahan dan pengurangan bilangan bulat,2) dapat memberikan pengalaman baru bagi siswa terhadap permainanmistar bilangan,dan3) mendorong minat dan motivasi siswa dalam pembelajaran matematika. Manfaat penelitian bagi guru adalah 1) mengetahui kekurangan yang ada dalam dirinya dan dapat dipergunakan perbaikan untuk pembelajaran berikutnya dan2) memiliki pengalaman dalam penerapan permainan mistarbilangan. Manfaat penelitian bagi sekolahadalah 1) memberikan sumbangan yang berguna untuk proses pembelajaran di sekolahdan2) memberikan dorongan untuk melakukan penelitian tindakan kelas terhadap guru lain.

\section{Kerangka Berpikir}

Berdasarkan rumusan masalah, tujuan, dan manfaat penelitian tersebut di atas didapat satu kerangka berpikir bahwa 1) Permainan mistar bilangan sebagai model pembelajaran mampu meningkatkan kemampuan siswa dalam menyelesaikan soal penjumlahan dan pengurangan bilangan bulat, 2) Kemampuan siswa dalam menyelesaikan soal penjumlahan dan pengurangan bilangan bulat, perlu dikembangkan untuk meningkatkan keterampilan dalam perkalian dan pembagian bilangan bulat, karena dasar dari perkalian dan pembagian adalah penjumlahan dan pengurangan, dan 3) Dengan permainan mistar bilangan diharapkan siswa lebih menguasai dalam penyelesaian soal penjumlahan dan pengurangan bilangan bulat dalam suasana pembelajaran yang menyenangkan.

\section{Hipotesis Tindakan}

Permainan mistar bilangan dapat meningkatkan aktivitas siswa dalam pembelajaran matematika tentang penjumlahan dan pengurangan bilangan bulat dan permainan mistar bilangan dapat meningkatkan prestasi siswa dalam menyelesaikan penjumlahan dan pengurangan bilangan bulat dalam pembelajaran matematika kelas IV, SDN 2 Temengeng, Kecamatan Sambong, Kabupaten Blora, semester 2, tahun pelajaran 2014/2015.

\section{Kajian Teori}

\section{Karakteristik Siswa Usia Sekolah Dasar}

Pembelajaran yang baik adalah pembelajaran yang menyenangkan, mendidik, dan membebaskan siswa dari semua belenggu. Untuk mencapai semua itu pembelajaran harus disesuaikan dengan kebutuhan, minat dan motivasi siswa, serta karakteristik siswa khususnya siswa sekolah dasar.

Karakteristik yang menonjol pada anak usia sekolah dasar adalah senang bermain, 
selalu bergerak, bekerja atau bermain dalam kelompok, dan senantiasa ingin melaksanakan atau merasakan sendiri (Sumantri, 2006:63).

Karakteristik pertama anak SD adalah senang bermain. Karakteristik ini menuntut guru untuk melaksanakan kegiatan pembelajaran yang bermuatan permainan di dalamnya. Guru hendaknya mengembangkan model pembelajaran yang serius tetapi santai seperti matematika, dengan mata pelajaran yang mengandung unsur permainan seperti pendidikan jasmani, seni budaya dan keterampilan (SBK) dan kesenian.

Karakteristik yang kedua dari anak usia SD adalah selalu bergerak. Oleh karena itu, guru hendaknya merancang model pembelajaran yang memungkinkan anak berpindah atau bergerak.

Karakteristik yang ketiga adalah anak senang bekerja atau bermaindalam kelompok. Dari pergaulannya dengan kelompok sebaya, anak belajar tentang aspek-aspek yang penting dalam proses sosialisasi, seperti belajar memenuhi aturan-aturan kelompok, belajar setia kawan, belajar tidak bergantung pada orang dewasa, belajar bekerja sama, belajar perilaku yang dapat diterima oleh lingkungannya, belajar menerima tanggung jawab, belajar bersaing dengan orang lain secara sportif, belajar olahraga dan permainan kelompok, serta belajar keadilan dan demokrasi. Karakteristik ini membawa implikasi bahwa guru harus merancang model pembelajaran yang memungkinkan anak untuk bekerja atau belajar dalam kelompok.
Guru dapat membentuk siswa menjadi kelompok kecil untuk mempelajari atau menyelesaikan suatu tugas secara kelompok.

Karakteristik yang keempat adalah anak senantiasa ingin melaksanakan atau merasakan sendiri. Ditinjau dari teori perkembangan kognitif, anak SD memasuki tahap operasional konkrit. Bagi anak SD, penjelasan guru tentang materi pelajaran akan lebih dipahami jika anak melaksanakan sendiri. Implikasi dari karakteristik ini, guru hendaknya merancang model pembelajaran yang memungkinkan anak terlibat langsung dalam proses pembelajaran, sekaligus dapat mengakomodasi potensi siswa tersebut untuk dapat terlibat secara aktif.

Menurut Dienes (dalam Dwiyanto, 2008), permainan matematika sangat penting, sebab operasi matematika dalam permainan tersebut menunjukkan secara konkrit dan lebih membimbing serta menajamkan pengertian matematika pada anak didik. Dienes membagi belajar menjadi tahap permainan bebas (free play), merupakan tahap belajar konsep yang aktivitasnya tidak berstruktur dan tidak diarahkan, sebab dalam setiap belajar tahap yang paling awal bermula dari permainan bebas.

Permainan dalam pembelajaran matematika diharapkan dapat menciptakan pembelajaran yang menyenangkan, sehingga siswa dapat mencintai matematika yang muaranya menghasilkan prestasi yang baik dalam bidang matematika. Menurut Haryono dan Jaino (2008: 17)proses pembelajaran 
yang menyenangkan adalah proses pembelajaran yang dapat menciptakan suasana dan iklim belajar yang kondusif, sehingga peserta didik merasa aman, nyaman, betah, dan asyik untuk mengikutinya. Untuk itu, pendidik perlu berpenampilan menarik, bersahabat, adil, penuh kasih, dan memiliki rasa humor.Namun,pendidikharus tetap berwibawa, disiplin, dan bertanggung jawab.

Senada dengan pendapat diatas, Vancleve's (2006: 7) menyebutkan bahwa kegiatan dan permainan sederhana dapat menciptakan pembelajaran matematika yang menyenangkan. Pengertian ini mengharapkan adanya pembelajaran matematika yang menyenangkan untuk meraih prestasi setinggi-tingginya.

\section{Operasi Hitung pada Bilangan Bulat} (Penjumlahan dan Pengurangan)

Operasi hitung bilangan bulat baru diperkenalkan kepada siswa Sekolah Dasar di kelas IV. Menurut Mustaqim dan Astuti(2008: 136), setelah mempelajari penjumlahan dan pengurangan bilangan bulat, siswa dapat terampil menggunakan bilangan bulat dalam menyelesaikan permasalahan mengenai bilangan bulat.

Banyak persoalan yang muncul pada sistem bilangan bulat bagi siswa sekolah dasar kelas IV, misalkan waktu mereka melakukan operasi hitung seperti: $3+(-5) ;(-7)+9 ;(-2)$ - (-4); 4 - 8; dan sebagainya. Persoalan yang muncul berkaitan dengan soal-soal tersebut adalah bagaimana memberikan penjelasan atau cara menanamkan pengertian operasi tersebut secara konkrit, karena diketahui bahwa pada umumnya siswa berpikir dari halhal yang bersifat konkret menuju hal-hal yang bersifat abstrak.

Untuk mengenalkan konsep operasi hitung pada sistem bilangan bulat dapat dilakukan melalui tigatahap, yaitu 1) tahap pengenalan konsep secara konkret, 2) tahap pengenalan konsep secara semi konkret atau semi abstrak, dan 3) tahap pengenalan konsep secara abstrak. Pada tahap pertama, ada dua model peragaan yang dapat dikembangkan, 1) menggunakan pendekatan himpunandan2) menggunakan pendekatan hukum kekekalan panjang (menggunakan pita garis bilangan, balok garis bilangan).Padatahap kedua, proses pengerjaan operasi hitungnya diarahkan menggunakan garis bilangan. Pada tahap ketiga, barulah siswa diperkenalkan dengan konsep-konsep operasi hitung yang bersifat abstrak.

\section{Permainan Mistar Bilangan}

Dalam permainan mistar bilangan ini, siswa dikenalkan tiga tahap permainan, yaitu 1) tahap pengenalan konsep secara konkret, 2) tahap pengenalan konsep secara semi konkret atau semi abstrak, dan 3) tahap pengenalan konsep secara abstrak.

Pada tahap pengenalan konsep secara konkret maka digunakan mistar bilangan.Mistar bilangan adalah alat yang lebih cenderung merupakan alat permainan matematika dan digunakan untuk 
mengenalkan atau melakukan operasi hitung dasar pada sistem bilangan bulat (Sugiarto dan Hidayah, 2008: 24). Mistar bilangan terbuat dari kayu, garis bilangan terbuat dari kayu penyangga dan papan kayu memanjang. Pada papan kayu memanjang tersebut dibuat skala yang berurutan dan jarak antarskalasama. Alat ini disebut kayu garis bilangan. Siswa menggerakkan model gambar-gambar yang telah dipersiapkan seperti boneka, binatang, mobil, orangorangan dengan loncatan-loncatan maju ataupun mundur diatas kayu garis bilangan dan setiap loncatannya mengandung makna atau mewakili bilangan-bilangan yang dioperasikan. Suasana inilah yang memungkinkan setiap anak atau kelompok dapat melakukan permainan.

Dalam menggunakan alat peraga kayu garis bilangan, harus pula memperhatikan prinsip kerja permainan ini. Prinsip kerja yang harus diperhatikan dalam melakukan operasi hitung penjumlahan maupun pengurangan dengan menggunakan permainan ini adalima, yaitu a) posisi awal, model harus berada pada skala nol, b) jika bilangan pertama bertanda positif maka model menghadap bilangan positif dan kemudian melangkah ke skala yang sesuai dengan besarnya bilangan pertama tersebut, namunjika bilangan pertamanya negatif maka model tetap menghadap bilangan positif, kemudian melangkah mundur ke skala sesuai dengan besarnya bilangan pertama tersebut, c)bila operasi penjumlahan maka model tetap menghadap bilangan positif, tetapi bila operasi pengurangan maka siswa berbalik arah, d) jika bilangan yang kedua positif maka model bergerak maju, jika negatif maka model bergerak mundur ke skala sesuai dengan besarnya bilangan kedua tersebut, dan e) skala terakhir yang ditempati model itulah sebagai hasil dari penjumlahan atau pengurangan.

Contoh penjumlahan bilangan negatif dengan negatif, $-2+(-6)=\ldots$ ? Untuk menjalankan proses peragaan bentuk operasi ini harus mengacu pada prinsip kerja sebagai berikut a) dari 0 , model melangkah mundur 2 satuan ke arah bilangan negatif,menunjukkan bilangan pertama (-2), b) karena operasi hitungnya mengenai penjumlahanoleh bilangan (-6), berarti model harus melangkah mundur sebanyak 6 satuan dari posisi 2 ,ternyata berhenti di skala -8 , dan c) posisi akhir pada langkah kedua tepat berada di atas skala -8 , menunjukkan hasil dari $-2+(-6)$. Jadi $-2+(-6)=-8$

Pada tahap pengenalan konsep secara semi konkret atau semi abstrak, proses pengerjaan operasi hitung pada sistem bilangan bulat diarahkan pada bagaimana menggunakan garis bilangan.Pada prinsipnya, cara kerja pada garis bilangan sama dengan cara kerja pada permainan balok garis bilangan, yaitu ditekankan pada maju untuk bilangan positif dan mundur untuk bilangan negatif. Namun, tetap menghadap posisi semula untuk penjumlahan dan berbalik arah untuk pengurangan. 
Tahap pengenalan konsep secara abstrak maka penggunaan alat peraga, permainan mistar bilangan dan garis bilangan untuk melakukan operasi hitung bilangan bulat mempunyai keterbatasan, karena tidak dapat menjangkau bilangan-bilangan yang cukup besar. Dengan demikian, guru harus menyampaikannya tanpa menggunakan alat bantu yang didahului oleh proses abstraksi. Setelah melalui proses abstraksi diharapkan pada saat guru mengenalkan konsep operasi hitung secara abstrak kepada siswa tidak terlalu mengalami kendala yang berarti.

Untuk memberikan pemahaman kepada siswa maka siswa diminta untuk memperhatikan kembali hasil-hasil penjumlahan dan pengurangan bilangan bulat pada waktu mereka menggunakan alat bantu dan permainan.

\section{Penelitian yang Relevan}

Penggunaan mistar bilangan dalam pembelajaran penjumlahan dan pengurangan bilangan bulat telah diteliti oleh Pribadi, Triono, dan Joharman (2012) yang berjudul "Penggunaan Media Mistar Geser dalam Peningkatan Pembelajaran Operasi Hitung Penjumlahan dan Pengurangan Bilangan Bulat Kelas IV Sekolah Dasar”. Mereka menyebutkan bahwa dari hasil evaluasi atau tes pemahaman siswa diperoleh nilai rata-rata kelas sebesar71,8 pada siklus I dan 74,7pada siklus II. Persentase kelulusan siswa pada setiap siklus sebesar $44,4 \%$ pada siklus I dan $77,7 \%$ pada siklus II. Penelitian yang sama juga dilaksanakan oleh Suhardi (2012) dengan hasil penelitian rata-rata pada tes sebelum tindakan hanya mencapai angka 50, siklus I rata-rata siswa mengalami peningkatan menjadi 59,4, dan pada siklus II mengalami peningkatan menjadi 90,6.

Hasil penelitian tersebut juga diperkuat olehpenelitian Surojo, Hudiono, dan Usman (2013) tentangpembelajaran bilangan bulat dengan menggunakan mistar hitung dapat meningkatkan hasil belajar siswa yang mempunyai kemampuan sedang dan rendah. Hasil yang sama juga disampaikan oleh Setyaningsih (2014) dalam penelitiannya yang berjudul "Penggunaan Media Mistar Bilangan untuk Meningkatkan Hasil Belajar Penjumlahan Bilangan Bulat Siswa Sekolah Dasar". Hasil penelitiannya menyebutkan bahwa hasil belajar siswa pada siklus Isebanyak $62,16 \%$ yang sudah tuntas, sedangkan 37,84\%belum tuntas. Kemudian pada siklus II ketuntasan hasilbelajar siswa mencapai $83,78 \%$, dan yang belum tuntasmencapai 16,23\%. Dengan demikian, pelaksanaanpembelajaran penjumlahan bilangan bulat denganmenggunakan media mistar bilangan dapat dikatakanberhasil karena sudah lebih dari $80 \%$ siswa yang tuntas.

Penelitian tentang bilangan bulat dengan media yang berbeda juga dilakukan oleh Dewi (2011) yang berjudul Penggunaan Garis Bilangan untuk Meningkatkan Kemampuan Hitung Bilangan Bulat Pada Siswa Kelas IV SDN 1 Karangduren Klaten, 
Tahun Pelajaran 2010/2011, menunjukkan keberhasilan peningkatan prestasi dari awal rata-rata 52,28, pada siklus1 menjadi 56,25 dan pada siklus2 menjadi 73,93. Penggunaan lidi untuk penjumlahan dan pengurangan bilangan bulat diteliti oleh Widiastuti (2012) dengan hasil belajar yang meningkat, siklus 1 sebesar 65,58 menjadi siklus II sebesar 75,29.

Di samping penggunaan media tertentu, penelitian tentang bilangan bulat juga melalui penerapan metode atau strategi belajar tertentu, seperti yang dilakukan oleh Sukmawati (2013) dengan judul penelitian "Peningkatan Keterampilan Penjumlahan dan Pengurangan Bilangan Bulat dengan Metode Inquiri pada Siswa Kelas II SD Negeri Dadirejo 02 Kecamatan Margorejo Kabupaten Pati”. Hasil penelitian itu terbukti adanya peningkatan hasil belajar pada siklus I siswa yang tuntas ada 11 anak atau 48\%, siswa yang belum tuntas ada 12 anak atau $52 \%$, dan pada siklus II siswa yang tuntas ada 22 anak atau 96\%, siswa yang belum tuntas ada 1 atau $4 \%$. Untari (2013) meneliti bilangan bulat dengan menerapkan metode inkuri. Hasil penelitiannya membuktikan peningkatan hasil belajar pada siklus I sebesar $61,53 \%$ dengan nilai rata-rata 78,46 selanjutnya pada siklus II meningkat menjadi $85,71 \%$ dengan nilai rata-rata 82,92.

\section{METODE PENELITIAN}

Penelitian ini menggunakan jenis penelitian tindakan kelas. Agar pelaksanaan penelitian dan perbaikan pembelajaran berlangsung dengan terarah maka setiap siklus selalu dilaksanakan dengan satu rangkaian langkah-langkah 1) Perencanaan, 2) Pelaksanaan, 3) Observasi, dan 4) Refleksi. Penelitian ini dilaksanakan di SDN 2 Temengeng, Kecamatan Sambong, Kabupaten Blora pada semester 2, tahun pelajaran 2014/2015. Pemilihan tempat ini didasarkan pada pertimbangan 1) adanya permasalahan dalam prestasi hasil belajar secara rata-rata rendah, 2) nilai hasil evaluasi pada mata pelajaran Matematika dibawah ketuntasan atau belum memenuhi KKM yang ditentukan, dan 3) siswa kurang antusias dalam pembelajaran Matematika terutama tentang penjumlahan dan pengurangan bilangan bulat.

Penelitian ini dilakukan sebanyak 2 siklus dan 1 pembelajaran awal. Tiap siklus berlangsung selama 140 menit (4x35 menit).

Subjek penelitian ini adalah siswa kelas IV SDN 2 Temengeng, Kecamatan Sambong, Kabupaten Blora pada semester 2, tahun pelajaran 2014/2015. Jumlah siswa sebanyak21 anak terdiri atas 10 siswa lakilaki dan 11 siswa perempuan.

Data penelitian yang dikumpulkan berupa informasi tentang proses pembelajaran matematika, motivasi siswa dalam mengikuti pembelajaran dan dalam mengerjakan tugastugas, serta kemampuan guru dalam menyusun rencana pembelajaran dan melaksanakan pembelajaran di kelas. Data penelitian itu dikumpulkan dari berbagai sumber yang meliputi informan atau nara 
sumber, siswa kelas IV, sekolah, dan guru kelas IV.Tempat dan peristiwa berlangsungnya aktivitas pembelajaran di ruang kelas IV. Dokumen atau arsipyang digunakan, antara lain berupa kurikulum, Rencana Pelaksanaan Pembelajaran (RPP), hasil kerja siswa berupa lembar kerja siswa dan lembar tes, dan buku penilaian.

Data hasil penelitian ini dilakukanvalidasi dengan menggunakan pendekatan triangulasi data, yaitu memeriksa data dari tiga pihak, guru/peneliti, kolaborator/teman sejawat sebagai pengamat, dan siswa. Sebagai contoh hasil pengamatan/observasi divalidasi dengan diskusi bersama antara guru dan pengamat,sedangkan instrumen tes diujikan kepada siswa pada akhir pembelajaran.

Data kuantitatif dianalisis secara deskriptif komparatif, yaitu membandingkan nilai tes kondisi awal, nilai siklus I dan siklus II,sedangkan data kualitatif dianalisis secara deskriptif kualitatif berdasarkan hasil observasi, refleksi, dan wawancara

\section{Deskripsi Pelaksanaan Pembelajaran Awal}

Deskripsi pelaksanaan pembelajaran awaladalahpembelajaran matematika pada materi penjumlahan dan pengurangan bilangan bulat disampaikan di kelas IV semester 2. Sebelum pelaksanaan pembelajaran dilakukan persiapan denganmenyusun rencana pembelajaran, menyiapkan alat peraga yang tepat, menyiapkan lembar observasi, lembar observasi perilaku siswa, dan menyiapkan alat tes.

Kegiatan awal, disajikan apersepsi dengan tanya jawab tentang penjumlahan dan pengurangan bilangan bulat. Disajikan pula motivasi dengan menyampaikan tujuan pembelajaran.

Kegiatan inti, siswa mendemonstrasikan cara menjumlahkan dan mengurangkan bilangan bulat dengan menggunakan garis bilangan,mengerjakan Lembar Kerja Siswa (LKS) secara kelompok, membahas LKS, dan pemantapan materi. Kegiatan akhir,memberikan evaluasi, mengoreksi, menilai, dan menganalisis, memberikan tindak lanjut (perbaikan, pengayaan,dan PR).Untuk mendapatkan data yang diperlukan dalam penelitian ini, pengamatan dilakukan dengan mengumpulkan data yang diperoleh darites yang diperlukan untuk mengukur hasil belajar siswa pada materi penjumlahan dan penguranganbilangan bulat. Nilai $\geq 65$ berarti siswa telah mencapai kriteria ketuntasan belajar, sedangkan nilai <55 berarti siswa belum mencapai kriteria ketuntasan belajar.Observasi/pengamatan terdiri daripengamatan tingkah laku siswa dilakukan oleh guru sebagai peneliti selama proses pembelajaran berlangsung, dengan menggunakan lembar pengamatan. Temuantemuan tingkah laku siswa diharapkan dapat menjadi bahan pendukung keberhasilan penelitian, pengamatan dilakukan untuk mengamati tingkah laku guru selama proses 
pembelajaran berlangsung, dilakukan oleh teman sejawat dengan menggunakan lembar pengamatan. Tingkah laku yang diamati menunjukkan perbaikan tingkah laku dalam pembelajaran.

Setelah melaksanakan seluruh proses pembelajaran awal, dilakukan refleksi untuk menilai keberhasilan pembelajaran, sehingga dapat menentukan tindakan selanjutnya terhadap penelitian yang sedang dilakukan.

\section{Deskripsi Pelaksanaan Pembelajaran}

\section{Siklus I}

Perbaikan pembelajaran siklus I dilakukan setelah guru melakukan refleksi terhadap nilai hasil pembelajaran awal pada identifikasi dan analisis permasalahan. Berdasarkan kesepakatan siswakelas IV yang tidak mencapai KKM maka dengan bantuan teman sejawat/guru melakukan perbaikan pembelajaran.Keterampilan guru terhadap langkah pembelajaran difokuskan pada keterampilan guru pada penerapan permainan mistar bilangan, perubahan tingkah laku siswa selama menerima perbaikan pembelajaran, perubahan hasil belajar siswa setelah menerima perbaikan pembelajaran.

Sebelum pelaksanaan pembelajaran dilakukan persiapan, yaitumenyusun rencana pembelajaran, menyiapkan alat peraga yang tepat, menyiapkan lembar observasi, lembar observasi perilaku siswa, dan menyiapkan alat tes. Pelaksanaan pembelajaran siklus I diamati dengan lembar pengamatan oleh teman sejawat.
Skenario pembelajarannya adalah 1) kegiatan awal, guru melakukan apersepsi dengan tanya jawab tentang penjumlahan dan pengurangan bilangan bulat, guru memberikan motivasi dengan menyampaikan tujuan pembelajaran dan2) kegiatan inti, siswa melihat demonstrasi permainan balok garis bilangan dan mencoba menggunakan permainan dalam penjumlahan dan pengurangan bilangan bulat, mengerjakan LKS secarakelompok, membahas LKS, dan menyimpulkan materi pembelajaran.

\section{Deskripsi Pembelajaran Siklus II}

Deskripsi pelaksanaan pembelajaran adalah perbaikan pembelajaran siklus II dilakukan setelah guru melakukan refleksi terhadap nilai hasil pembelajaran siklus I pada identifikasi dan analisis permasalahan. Pembelajaran siklus II juga diamati dengan lembar pengamatan oleh pengamat yang difokuskan pada tingkah laku guru dan siswa selama proses pembelajaran.

Skenario pembelajarannya adalah 1) kegiatan awal,guru melakukan apersepsi dengan tanya jawab tentang penjumlahan dan pengurangan bilangan bulat, guru memberikan motivasi dengan menyampaikan tujuan pembelajaran, 2) kegiatan inti,guru bersama siswa mendemonstrasikan cara bermain mistar bilangan dalam penjumlahan dan pengurangan bilangan bulat, mengerjakan LKS secara kelompok dengan memperagakan permainan mistar bilangan, membahas LKS dan menyimpulkan materi pembelajaran, 
pemantapan materi, 3) kegiatan akhir, memberikan evaluasi, mengoreksi, menilai, dan menganalisis, memberikan tindak lanjut (perbaikan, pengayaan,dan PR).

\section{HASIL DAN PEMBAHASAN}

\section{Hasil Penelitian}

Hasil penelitian tentang proses pembelajaran dan hasil belajar siswa dalam pembelajaran matematika tentang penjumlahan dan pengurangan bilangan bulat melalui permainan mistar bilangan pada siswa kelas IV SDN 2 Temengeng, Kecamatan Sambong, Kabupaten Blora, pada semester 2, tahun pelajaran 2014/2015, dipaparkan seperti berikut.

\section{Hasil Pembelajaran Awal}

\section{Proses Pembelajaran}

Pembelajaran awal tentang penjumlahan dan pengurangan bilangan bulatberlangsung satu pertemuan. Aktivitas pembelajaran yang diamati meliputi mempersiapkan alat, keberanianbertanya, menjawab pertanyaan, memperagakan mistar bilangan,bermain mistar bilangan, kerja kelompok, menanggapi pendapatteman, dan merapikan alat permainan. Hasil aktivitas siswa selengkapnya dapat dilihat dalam Tabel 1.

\section{Tabel 1 Aktivitas SiswaPembelajaran Awal}

\begin{tabular}{clcc} 
No & \multicolumn{1}{c}{ Aktivitas Siswa } & $\begin{array}{c}\text { Jumlah } \\
\text { Siswa }\end{array}$ & $\begin{array}{c}\text { Persentase } \\
1\end{array}$ \\
2 & Mempersiapkan alat pembelajaran & 5 & $23,8 \%$ \\
3 & Keberanian Bertanya & 3 & $14,3 \%$ \\
4 & Menjawab pertanyaan (dari guru, siswa) & 4 & $19,0 \%$ \\
5 & Bermain mistar bilangan (Penjumlahan, Pengurangan) & 4 & $19,0 \%$ \\
6 & Kerja kelompok & 4 & $19,0 \%$ \\
7 & Menanggapi pendapat teman/berpendapat & 10 & $47,6 \%$ \\
8 & Merapikan alat pembelajaran. & 6 & $28,6 \%$ \\
Rata-Rata & 3 & $14,3 \%$ \\
Kriteria & & $\mathbf{2 3 , 2 \%}$
\end{tabular}

Tabel 1 menunjukkan bahwa aktivitas siswa dalam pembelajaran sangat kurangkarena sebagian besar siswa masih pasif. Siswa yang aktif tidak mencapai $25 \%$. Dalam pembelajaran awal ini belum sepenuhnya menggunakan mistar bilangan untuk menjelaskan penjumlahan dan pengurangan bilangan bulat, hanya sebatas mengenalkan bilangan bulat,sehingga aktivitas pembelajaran masih didominasi oleh guru, terbukti dengan rata-rata aktivitas siswa dalam pembelajaran sebesar23,2\%.

\section{Prestasi}

Hasil belajar yang diketahui setelah diadakan tes formatif pada pembelajaran awal disajikan dalam Tabel 2. Berdasarkan Tabel 2 
tentang hasil tes formatif materi penjumlahan dan pengurangan bilangan bulat, dapat ditemukan siswa yang belum berhasil memperoleh ketuntasan belajar maupun siswa yang sudah mencapai ketuntasan belajar.Dengan menganalisis daftar nilai ketuntasan maka didapatkan siswa yang mendapat nilai tuntas sebesar 28,6\%, sedangkan siswa yang belum mendapat nilai tuntas sebesar 71,4\%. Rata-rata kelas tercapai 45,24 belum mencapai KKM yang ditentukan. Oleh karena itu, perlu diadakan perbaikan pembelajaran.

Tabel 2 Analisis Hasil Tes Penjumlahan dan Pengurangan Bilangan Bulat Pembelajaran Awal

$\begin{array}{lccc}\text { Nilai } & \text { Frekuensi } & \text { Jumlah } & \text { Kategori } \\ 10 & - & & \\ 20 & 3 & 60 & \text { Tidak Tuntas } \\ 30 & 4 & 120 & \text { Tidak Tuntas } \\ 40 & 3 & 120 & \text { Tidak Tuntas } \\ 50 & 5 & 250 & \text { Tidak Tuntas } \\ 60 & 3 & 180 & \text { Tuntas } \\ 70 & 2 & 140 & \text { Tuntas } \\ 80 & 1 & 80 & \text { Tuntas } \\ 90 & - & & \\ 100 & - & & \\ \text { Jumlah Nilai } & & 950 & \\ \text { Rerata } & & 45,24 & \\ \text { Persentase Ketuntasan Klasikal } & 28,6 \% & \\ \text { KKM } & & 55 & \end{array}$

\section{Hasil Pembelajaran siklus I}

\section{Proses Pembelajaran}

Secara umum dapat dikatakan bahwa pelaksanaan perbaikan pembelajaran pada siklus I berjalan cukup baik sesuai dengan rencana pembelajaran.

Pembelajaran diawali dengan penyampaian motivasi berupa penjelasan tujuan, apersepsi dan penjelasan umum tentang penjumlahan dan pengurangan bilangan bulat. Penjelasan diawali dengan penggunaan mistar bilangan melalui peragaan permainan mistar bilangan. Siswa diberi kesempatan untuk memperagakan permainan mistar bilangan dengan contoh beberapa soal. Secara bergantian siswa dapat mencoba untuk menggunakan mistar bilangan.

Pembelajaran dilanjutkan dengan membagi LKS untuk dikerjakan siswa secara kelompok, yang penyelesaiannya menggunakan mistar bilangan. Diskusi kelompok selesai dilanjutkan presentasi kelompok atau diskusi kelas. Dalam diskusi kelas siswa saling menanggapi, bertanya, dan menjawab. Hasil aktivitas siswa dalam pembelajaran disajikan dalam Tabel 3 
Tabel 3 Aktivitas Siswa Pembelajaran Siklus I

\begin{tabular}{cl} 
No & \multicolumn{1}{c}{ Aktivitas Siswa } \\
1 & Mempersiapkan alat pembelajaran \\
2 & Keberanian Bertanya \\
3 & Menjawab pertanyaan (dari guru, siswa) \\
4 & Memperagakan mistar bilangan \\
5 & Bermain mistar bilangan (Penjumlahan, Pengurangan) \\
6 & Kerja kelompok \\
7 & Menanggapi pendapat teman/berpendapat \\
8 & Merapikan alat pembelajaran. \\
Rata-Rata \\
Kriteria
\end{tabular}

$\begin{array}{cc}\begin{array}{cc}\text { Jumlah } \\ \text { Siswa }\end{array} & \text { Persentase } \\ 12 & 57,1 \% \\ 10 & 47,6 \% \\ 15 & 71,4 \% \\ 10 & 47,6 \% \\ 13 & 61,9 \% \\ 16 & 76,2 \% \\ 14 & 66,7 \% \\ 15 & 71,4 \% \\ & \mathbf{6 2 , 5 \%} \\ & \text { Cukup }\end{array}$

Berdasarkan Tabel 3 ditemukan bahwa aktivitas siswa secara keseluruhan cukup baik dengan rata-rata $62,5 \%$. Hal ini ada peningkatan jikadibandingkan pembelajaran awal sebesar $23,2 \%$. Peningkatan ini ditandai adanya peningkatan siswa dalam mempersiapkan alat, keberanian bertanya, menjawab pertanyaan, memperagakan mistar bilangan, belajar bermain mistar bilangan, kerja kelompok, dan saling tukar pendapat.

\section{Prestasi}

Hasil belajar pembelajaran siklus I dapat dibaca pada Tabel 4.Berdasarkan Tabel 4, hasil belajar siswa melalui tes formatif terdapatpeningkatan. Terlihat dari siswa yang mendapat nilai tuntas sebesar $57,1 \%$, sedangkan yang belum tuntas berkurang menjadi $42,9 \%$. Rata-rata kelas meningkat menjadi 60,48. Kalau dibandingkan dengan pembelajaran awal hasil pembelajaran siklus I ini lebih tinggi. Rata-rata kelas telah memenuhi $\mathrm{KKM}$, tetapi rata-rata kelas dan tuntas klasikal belum memenuhi indikator kinerja penelitian ini sebesar 75,00 untuk rata-rata kelas dan 75\% untuk tuntas klasikal. Oleh karena itu, perbaikan pembelajaran dilanjutkan pada pembelajaran siklus II. 


\section{Tabel 4 Analisis Hasil Tes Penjumlahan dan Pengurangan Bilangan Bulat Pembelajaran Siklus I}

$\begin{array}{lccc}\text { Nilai } & \text { Frekuensi } & \text { Jumlah } & \text { Kategori } \\ 10 & - & - & - \\ 20 & - & - & - \\ 30 & - & - & - \\ 40 & 4 & 160 & \text { Tidak Tuntas } \\ 50 & 5 & 250 & \text { Tidak Tuntas } \\ 60 & 3 & 180 & \text { Tuntas } \\ 70 & 4 & 280 & \text { Tuntas } \\ 80 & 5 & 400 & \text { Tuntas } \\ 90 & - & - & - \\ 100 & - & - & - \\ \text { Jumlah Nilai } & & 1.270 & \\ \text { Rerata } & & 60,48 & \\ \text { Persentase Ketuntasan Klasikal } & 57,1 \% & \\ \text { KKM } & & 55 & \end{array}$

\section{Hasil Pembelajaran Siklus II}

titik tolak untuk meningkatkan aktivitas dan Proses Pembelajaran

hasil belajar pada pembelajaran siklus II. Hasil

Proses pembelajaran siklus II berjalan baik. pengamatan aktivitas siswa pembelajaran Keberhasilan pembelajaran siklus I dijadikan siklus II disajikan dalam Tabel 5.

Tabel 5 Aktivitas Siswa Pembelajaran Siklus II

\begin{tabular}{|c|c|c|c|}
\hline No & Aktivitas Siswa & $\begin{array}{c}\text { Jumlah } \\
\text { Siswa }\end{array}$ & Persentase \\
\hline 1 & Mempersiapkan alat pembelajaran & 18 & $85,7 \%$ \\
\hline 2 & Keberanian Bertanya & 18 & $85,7 \%$ \\
\hline 3 & Menjawab pertanyaan (dari guru, siswa) & 17 & $81,0 \%$ \\
\hline 4 & Memperagakan mistar bilangan & 19 & $90,5 \%$ \\
\hline 5 & Bermain mistar bilangan (Penjumlahan, Pengurangan) & 18 & $85,7 \%$ \\
\hline 6 & Kerja kelompok & 19 & $90,5 \%$ \\
\hline 7 & Menanggapi pendapat teman/berpendapat & 17 & $81,0 \%$ \\
\hline 8 & Merapikan alat pembelajaran & 16 & $76,2 \%$ \\
\hline \multicolumn{3}{|c|}{ Rata-Rata } & $84,5 \%$ \\
\hline \multicolumn{3}{|c|}{ Kriteria } & Baik \\
\hline
\end{tabular}

Berdasarkan data pada Tabel melakukan aktivitas yang diminta sesuai 5ditunjukkan bahwa aktivitas siswa dalam kegiatan pembelajaran seperti mempersiapkan pembelajaran siklus II baik dengan capaian alat, keberanian bertanya, menjawab rata-rata $84,5 \%$. Hal ini berarti ada pertanyaan, memperagakan permainan mistar peningkatan yang baik dari pembelajaran bilangan, bermain mistar bilangan, kerja siklus I. Sebagian besar siswa sudah mulai 
kelompok, menanggap pendapat teman, dan merapikanalat pelajaran.

\section{Prestasi}

Hasil tes yang dilaksanakan pada akhir pembelajaran siklus II disajikan pada Tabel 6.Dengan menganalisis Tabel 6 tentang hasil tes formatif materi penjumlahan dan pengurangan bilangan bulat didapatkan bahwa pada siklus II nilai ketuntasan siswa mengalami kenaikan lebih besar, yaitu dari $57,1 \%$ pada siklus I menjadi $85,7 \%$ pada siklus II, sedangkan nilai yang belum tuntas menjadi semakin turun dari 42,9\% (9 siswa) pada siklus I menjadi 14,3\% (3 siswa) pada siklus II. Peningkatan prestasi juga terjadi pada siklus II ini. Semula rata-rata kelas 60,48 pada siklus I menjadi 75,24 pada pembelajaran siklus II.

Tabel 6 Analisis Hasil Tes Penjumlahan dan Pengurangan Bilangan Bulat Pembelajaran Siklus II

$\begin{array}{cccc}\text { Nilai } & \text { Frekuensi } & \text { Jumlah } & \text { Kategori } \\ 10 & - & - & - \\ 20 & - & - & - \\ 30 & - & - & - \\ 40 & - & - & - \\ 50 & 3 & 150 & \text { Tidak Tuntas } \\ 60 & 1 & 60 & \text { Tuntas } \\ 70 & 4 & 280 & \text { Tuntas } \\ 80 & 8 & 640 & \text { Tuntas } \\ 90 & 5 & 450 & \text { Tuntas } \\ 100 & - & - & - \\ \text { Jumlah Nilai } & & 1.580 & \\ \text { Rerata } & & 75,24 & \\ \text { Persentase Ketuntasan Klasikal } & 85,7 \% & \\ \text { KKM } & & 55 & \end{array}$

\section{Pembahasan}

Proses perbaikan pembelajaran dalam penelitian ini, disajikan dalam dua siklus yang telah menghasilkan temuan-temuan, yang selanjutnya perlu dibahas untuk mendapat simpulan. Bersama teman sejawat, didiskusikan temuan-temuan berupa hasil pengamatan aktivitas siswa dalam proses pembelajaran dan hasil belajar siswa selama 2 siklus perbaikan pembelajaran seperti disajikan berikut.

\section{Proses Pembelajaran}

Hasil pengamatan tingkah laku siswa yang diharapkan sudah lebih baik daripada pembelajaran awal, tetapi masih jauh dari yang diharapkan. Hal ini dapat dilihat pada Tabel 7, dari masih rendahnya persentase aktivitas siswa selama proses perbaikan pembelajaran siklus I, yaitu mempersiapkan alat, keberanian bertanya, menjawab pertanyaan, memperagakan permainan mistar bilangan, bermain mistar bilangan,kerja kelompok,menanggapi pendapat teman dalam diskusi kelas, dan merapikan alat pelajaran 
masih dalam kategori cukup dengan rata-rata 62,5. Walaupun aktivitas pembelajaran siklus I ini cukup, namun sudah ada peningkatan aktivitas jika dibandingkan dengan pembelajaran awal yang hanya mencapai $23,2 \%$ rata-rata aktivitas siswa.

Tabel 7 Perbandingan Aktivitas Siswa, Pembelajaran Awal, Siklus I dan Siklus II

\begin{tabular}{|c|c|c|c|c|c|c|c|}
\hline \multirow{2}{*}{ No. } & \multirow{2}{*}{ Aktivitas Siswa } & \multicolumn{3}{|c|}{ Siswa } & \multicolumn{3}{|c|}{ Persentase } \\
\hline & & Awal & Siklus I & Siklus II & Awal & Siklus I & Siklus II \\
\hline 1 & Mempersiapkan alat pelajaran & 5 & 12 & 18 & 23,8 & 57,1 & 85,7 \\
\hline 2 & Keberanian bertanya & 3 & 10 & 18 & 14,3 & 47,6 & 85,7 \\
\hline 3 & Menjawab pertanyaan (dari guru, siswa) & 4 & 15 & 17 & 19,0 & 71,4 & 81,0 \\
\hline 4 & Memperagakan mistar bilangan & 4 & 10 & 19 & 19,0 & 47,6 & 90,5 \\
\hline 5 & Bermain mistar bilangan & 4 & 13 & 18 & 19,0 & 61,9 & 85,7 \\
\hline 6 & Kerja kelompok & 10 & 16 & 19 & 47,6 & 76,2 & 90,5 \\
\hline 7 & Menanggapi pendapat teman & 6 & 14 & 17 & 28,6 & 66,7 & 81,0 \\
\hline \multirow[t]{3}{*}{8} & Merapikan alat pembelajaran & 3 & 15 & 16 & 14,3 & 71,4 & 76,2 \\
\hline & Jumlah Siswa & 21 & 21 & 21 & 23,2 & 62,5 & 84,5 \\
\hline & Kriteria & & & & Kurang & Cukup & Baik \\
\hline
\end{tabular}

Berbekal pengalaman pembelajaran siklus I, pada pembelajaran siklus II diharapkan proses pembelajaran siklus II lebih menarik dan meningkatkan aktivitas siswa. Siswa yang semula ragu-ragu dalam bermain mistar bilangan lebih berani untuk mencoba memecahkan soal penjumlahan dan pengurangan dengan menggunakan mistar bilangan tersebut. Demikian juga sikap siswa untuk bertanya, menjawab, diskusi dan menanggapi setiap pendapat atau pernyataan teman dan guru, lebih meningkat. Terbukti dengan permainan mistar bilangan sebesar86\% siswa mau mencoba dan memperagakan permainan tersebut. Keseluruhan aktivitas siswa dalam pembelajaran siklus II yang diamati mencapai rata-rata $84,5 \%$. Pencapaian ini sebagai bukti kalau siswa sudah tertarik dan senang dengan permainan mistar bilangan dalam pembelajaran matematika tentang penjumlahan dan pengurangan bilangan bulat. Hal ini sesuai dengan pendapat Vancleve's (2006: 7) bahwa kegiatan dan permainan sederhana dapat menciptakan pembelajaran matematika yang menyenangkan. Pembelajaran yang menyenangkan inilah yang dapat meningkatkan keterlibatan siswa secara optimal dalam pembelajaran.

Peningkatan aktivitas siswa dalam pembelajaran penjumlahan dan pengurangan bilangan bulat itu menunjukkan bahwa keterlibatan siswa dalam pembelajaran itu sudah tinggi. Terbukti dari pembelajaran awal $23,2 \%$, meningkat menjadi $62,5 \%$ pada pembelajaran siklus I, dan meningkat lagi menjadi $84,5 \%$ pada pembelajaran siklus II. Hal ini menunjukkan bahwa hipotesis yang diajukan dapat diterima, yaitu permainan mistar bilangan dapat meningkatkan aktivitas 
siswa dalam pembelajaran matematika tentang penjumlahan dan pengurangan bilangan bulat.

\section{PrestasiHasil Belajar}

Tingkat kemampuan siswa memahami tentang penjumlahan dan pengurangan bilangan bulat dapat dilihat pada hasil tes akhir setiap pembelajaran dapat dilihat pada Tabel 8. Pada pembelajaran awal kemampuan siswa masih rendah yang dibuktikan dengan hasil tes dengan tingkat tuntas klasikal hanya 28,6\% dan rata-rata kelas baru mencapai 45,24. Ketidakberhasilan ini ditandai dengan hasil belajar yang masih di bawah standar KKM, menunjukkan bahwa siswa belum mampu menguasai materi penjumlahan dan pengurangan bilangan bulat. Untuk membantu siswa menguasai materi ini, disajikan bantuan permainan mistar bilangan dalam pembelajaran penjumlahan dan pengurangan bilangan bulat.

Tabel 8 Perbandingan Hasil Tes Penjumlahan dan Pengurangan Bilangan Bulat

Pembelajaran Awal, Siklus I dan Siklus II

\begin{tabular}{|c|c|c|c|c|c|c|c|c|c|c|}
\hline \multirow{2}{*}{ No. } & \multirow{2}{*}{ Nilai } & \multicolumn{3}{|c|}{ Frekuensi } & \multicolumn{3}{|c|}{ Jumlah } & \multicolumn{3}{|c|}{ Kategori } \\
\hline & & Awal & Siklus I & Siklus II & Awal & Siklus I & Siklus II & Awal & Siklus I & Siklus II \\
\hline 1 & 10 & 0 & 0 & 0 & 0 & 0 & 0 & & & \\
\hline 2 & 20 & 3 & 0 & 0 & 60 & 0 & 0 & Tidak tuntas & & \\
\hline 3 & 30 & 4 & 0 & 0 & 120 & 0 & 0 & Tidak tuntas & & \\
\hline 4 & 40 & 3 & 4 & 0 & 120 & 160 & 0 & Tidak tuntas & Tidak tuntas & \\
\hline 5 & 50 & 5 & 5 & 3 & 250 & 250 & 150 & Tidak tuntas & Tidak tuntas & Tidak tuntas \\
\hline 6 & 60 & 3 & 3 & 1 & 180 & 180 & 60 & Tuntas & Tuntas & Tuntas \\
\hline 7 & 70 & 2 & 4 & 4 & 140 & 280 & 280 & Tuntas & Tuntas & Tuntas \\
\hline 8 & 80 & 1 & 5 & 8 & 80 & 400 & 640 & Tuntas & Tuntas & Tuntas \\
\hline 9 & 90 & 0 & 0 & 5 & 0 & 0 & 450 & - & & Tuntas \\
\hline 10 & 100 & 0 & 0 & 0 & 0 & 0 & 0 & & & \\
\hline \multicolumn{2}{|c|}{ Jumlah nilai } & 21 & 21 & 21 & 950 & 1270 & 1580 & & & \\
\hline \multicolumn{5}{|c|}{ Rerata } & 45,24 & 60,48 & 75,24 & & & \\
\hline \multicolumn{5}{|c|}{ Persentase Ketuntasan } & 28,60 & 57,10 & 85,70 & & & \\
\hline \multicolumn{5}{|c|}{ KKM } & 55 & 55 & 55 & & & \\
\hline
\end{tabular}

Pembelajaran siklus Iyang sudah menggunakan permainan mistar bilangan menunjukkan hasil yang lebih baik jikadibandingkan dengan pada pembelajaran awal. Hasilrata-rata kelas mencapai 60,48 dengan tuntas klasikal mencapai 57,1\%. Hal ini berartiada peningkatan biladibandingkan pada pembelajaran awal. Rata-rata kelas telah melampaui KKM. Namun,tuntas klasikal belum mencapai indikator kinerja yang telah ditetapkan,sehingga pembelajaran dilanjutkan pada siklus II.

Keberhasilan pada pembelajaran siklus I mendorong pembelajaran siklus II lebih antusias, sehingga aktivitas siswa meningkat. Tingkat aktivitas siswa yang meningkat berdampak pada kemampuan siswa untuk menguasai materi penjumlahan dan 
pengurangan bilangan bulat jugameningkat. Siswa lebih berani mempraktikkan cara-cara penyelesaian soal-soal penjumlahan dan pengurangan bilangan bulat, sehingga makin terampil menghitung operasi tersebut. Hal ini ditandai pada hasil tes akhir pembelajaran siklus II yang mencapai 75,24 rata-rata kelas,sedangkan tuntas klasikal mencapai $85,7 \%$.Hal ini menunjukkan bahwa hipotesis penelitian yang diajukan dapat diterima, yaitu permainan mistar bilangan dapat meningkatkan prestasi siswa dalam menyelesaikan penjumlahan dan pengurangan bilangan bulat dalam pembelajaran matematika kelas IV, SDN 2 Temengeng, Kecamatan Sambong, Kabupaten Blora, semester 2, tahun pelajaran 2014/2015.

Ternyata setelah mempelajari penjumlahan dan pengurangan bilangan bulat dengan seksama dan dibantu dengan permainan mistar bilangan siswa dapat terampil menggunakan bilangan bulat dalam menyelesaikan soal-soal bilangan bulat. Hal ini sesuai dengan pendapat Mustaqim dan Astuti (2008: 136) setelah mempelajari penjumlahan dan pengurangan bilangan bulat, siswa dapat terampil menggunakan bilangan bulat dalam menyelesaikan permasalahan mengenai bilangan bulat.

\section{KESIMPULAN DAN SARAN}

\section{Simpulan}

Dari hasil penelitian tindakan kelas ini sesuai dengan apa yang direncanakan dapat disimpulkan bahwa 1) proses pembelajaran dengan penggunaan model permainan mistar bilangan dapat meningkatkan aktivitas siswa kelas IV SDN 2 Temengeng, Kecamatan Sambong, Kabupaten Blora, seperti bertanya, diskusi, permainan mistar bilangan, latihan soal, dan presentasi siswa. Hal ini ditandai dengan peningkatan rata-rata aktivitas siswa dari pembelajaran awal sebesar 23,2\% (kurang), menjadi 62,5\% (cukup) pada siklus I, dan $84,5 \%$ (baik) pada siklus II, 2) pembelajaran melalui permainan mistar bilangan dapat meningkatkan prestasi siswa tentang penjumlahan dan pengurangan bilangan bulat. Hal ini ditandai dengan peningkatan rata-rata kelas dari pembelajaran awal 45,24 menjadi 60,48 pada siklus I dan 75,24 pada siklus II. Tuntas klasikal juga meningkat dari $28,6 \%$ pada pembelajaran awal menjadi $57,1 \%$ pada siklus I dan $85,7 \%$ pada siklus II.

\section{Saran}

Aktivitas pembelajaran penjumlahan dan pengurangan bilangan bulat pada siswa kelas IV SD Negeri 2 Temengeng seperti bertanya, diskusi, bermain mistar bilangan perlu ditingkatkan terus agar pembelajaran tetap optimal, salah satunya melalui penggunaan alat mistar bilangan. Prestasi belajar yang baik tentang penjumlahan dan pengurangan bilangan bulat harus dipertahankan bila perlu ditingkatkan, melalui latihan-latihan dan pengoptimalan penggunaan alat peraga. Oleh karena itu, guru hendaknya melaksanakan tindakan-tindakan perbaikan tersebut di atas.Bahkan,perlu dicari 
alternatif lain yang dapat menambah kemampuan siswa.Kepada teman guru agar mencari alternatif lain model permainan agar pembelajaran senantiasa menyenangkan.Untuk sekolah agar dapat mendokumentasikan segala hasil karya guru termasuk hasil penelitian tindakan kelas ini, agar dapat dinikmati oleh sesama guru. 


\section{DAFTAR PUSTAKA}

David, Glover, 2006. Seri Ensiklopedia Anak, A - Z, Matematika, Volume 3 Q-Z. Bandung: Grafindo Media Pratama.

Dewi, Ike Ligasari, 2011. Penggunaan Garis Bilangan untuk Meningkatkan Kemampuan Hitung Bilangan Bulat Pada Siswa Kelas IV SDN 1 Karangduren Klaten Tahun Pelajaran 2010/2011. Skripsi, diakses dari http://eprints.uns.ac.id, tanggal 2 April 2015.

Dwiyanto, 2008. Teori-Teori Belajar Matematika. Semarang: Unnes.

Haryono dan Jaino, 2008. Bahan Ajar, Prinsip-prinsip Pembelajaran yang Mendidik di SD, Program Sertifikasi Guru dalam Jabatan Melalui Jalur Pendidikan. Semarang: Unnes.

Mustaqim, Burhan \& Ary Astuti, 2008. Ayo Belajar Matematika, Untuk SD dan MI Kelas IV. Jakarta: Pusat Perbukuan, Departemen Pendidikan Nasional.

Pribadi, Triono, dan Joharman, 2012. Penggunaan Media Mistar Geser dalam Peningkatan Pembelajaran Operasi Hitung Penjumlahan dan Pengurangan Bilangan Bulat Kelas IV Sekolah Dasar,diakses dari jurnal.fkip.uns.ac.id, tanggal 1 April 2015.

Setyaningsih, 2014. Penggunaan Media Mistar Bilangan untuk Meningkatkan Hasil Belajar Penjumlahan Bilangan Bulat Siswa Sekolah Dasar.Jurnal PGSD, Volume 02, Nomor 02 Tahun 2014, PGD FIP Unesa, diakses dari ejournal.unesa.ac.id/article, tanggal 1 April 2015. 3

Sugiarto dan Isti Hidayah, 2008. Buku Petunjuk Penggunan Alat Peraga Matematika UntukPendidikan Dasar Sesuai Dengan KTSP. Semarang: Laboratorium Matematika Unnes.

Suhardi, 2012. Peningkatan Pemahaman Konsep Penjumlahan Dan Penguranngan Pada Bilangan Bulat Dengan Menggunakan Media Mistar Bilangan Kelas V A SDN Guwosari Kabupaten Bantul. Tesis, Skripsi, diakses dari http://eprints.uny.ac.id, tanggal 2 April 2015.

Sukmawati, Lina, 2013. Peningkatan Keterampilan Penjumlahan dan Pengurangan Bilangan Bulat Dengan Metode Inquiri Pada Siswa Kelas II SD Negeri Dadirejo 02 Kecamatan Margorejo Kabupaten Pati. Skrisi, diakses dari eprints.ums.ac.id, tanggal 3 April 2015.

Sumantri, Mulyani, 2006. Perkembangan Peserta Didik. Jakarta: Universitas Terbuka.

Surojo, Hudiono, dan Usman, 2013. Pemanfaatan Media Mistar Hitung Untuk Pemerolehan Hasil Belajar Bilangan Bulat di Kelas VII.Tesis, diakses dari jurnal.untan.ac.id/index.php/jpdpb/article, tanggal 1 April 2015.

Untari, Tri, 2013. Meningkatkan Pemahaman Konsep Penjumlahan Dan Pengurangan Bilangan Bulat Menggunakan Model Pembelajaran Quantum Teachingg Pada Siswa Kelas IV SDN Kulwaru Kulon. Skripsi, diakses dari eprints.uny.ac.id/13961/1/SKRIPSI, tanggal 4 April 2015.

Vancleave's, Janice, 2006. Matematika untuk Anak, Kegiatan-Kegiatan Sederhana yang Membuat Belajar Matematika Menjadi Menyenangkan. Bandung: Pakar Raya.

Widiastuti, 2012. Upaya Meningkatkan Hasil Belajar Matematika Melalui Penggunaan Media Lidi Pada Penjumlahan Bilangan Bulat Pada Siswa Kelas IV Di SD Negeri Banaran Semester 
II Tahun Ajaran 2011/2012. Skripsi, Program Studi PGSD, Fakutas Keguruan dan Ilmu Pendidikan, Universitas Kristen Satya Wacana Salatiga, diakses dari repository.uksw.edu, tanggal 3 April 2015. 